\title{
Individual borrowing and default behaviour in surplus and constrained credit environments: evidence from India
}

\author{
Padmavathi Koride* and Anjula Gurtoo \\ DOMS, Indian Institute of Science, Sir C. V. Raman Road, Bengaluru 560 012, India
}

The present article studies borrowing behaviour between credit surplus and credit constrained environments in the context of microfinance, with respect to rural borrowing. Surplus and constrained environments get defined based on the number of the statepromoted self help groups (SHGs) in the district, and the volume of credit disbursed through these SHGs. Four hundred nineteen respondents comprising of farmers, off-farm workers, farm labourers, small businesspersons, SHG members and chit-fund or cooperative members were interviewed in the surplus district of Chittoor and the constrained district of Nalgonda in the erstwhile state of Andhra Pradesh. Statistical analyses comprising of OLS, binary logistic regression, ANOVA, $t$-test and chi-square tests show that surplus environments offer more adverse credit terms, especially for farmers and farm labourers. Further, surplus causes over-borrowing and defaults. Constraint propels planned repayments. Both the environments offer varying credit terms across trades. We also observe better lending terms when farmers and traders are among lenders in a constraint environment. Interlinking factor markets like land, labour and capital in a constrained environment leads to efficient outcomes, reinforcing the theory of New Institutional Economics.

Keywords: Behaviour, borrower, constraint, credit terms, surplus.

CREDIT access enhanced food security and augmented farm productivity ${ }^{1}$. Simultaneously credit constraint reduced income-generating opportunities and decreased child nutrition ${ }^{2}$. For example, credit scarcity increased the shadow price of land in Tunisia ${ }^{3}$, whereas extending credit helped income augmentation, increased the profitability of the micro-entrepreneurs, and increased selfemployment. In Bosnia and Herzegovina extending credit reduced dependence on wage labour and improved food security, lifting the borrowers out of poverty ${ }^{4,5}$.

Plenty of borrowing opportunities, however, led to over-borrowing well beyond the repayment capacity ${ }^{6-8}$. This led to high defaults and mass defaults, sending the

\footnotetext{
*For correspondence. (e-mail: padmakoride@gmail.com)
}

Micro Financial Institutions (MFIs) and other lenders into a tailspin, prompting more adverse credit terms. The borrowers in surplus successfully hid their repayment intentions, and borrowed from multiple sources and defaulted strategically. Literature on surplus recommended credit registries for reducing information asymmetry and hence the default rates ${ }^{9}$.

The study is based on face to face interviews of 419 borrowers, 210 from the credit surplus district of Chittoor and 209 from the credit constrained district of Nalgonda in Andhra Pradesh. The study examines the $2 \times 2$ matrix of borrowing and default comparison between surplus and constrained environments; and a comparison of credit flow across trades, where surplus and constrained districts are drawn from the same socio-economic milieu.

We study three research questions, namely, a comparison of borrowing behaviour between credit surplus and constraint; a comparison of default behaviour between the two credit environments; and a comparison of the flow of credit across trades between surplus and constraint. The respondents are systematically sampled from landed farmers, landless labourers, off-farm workers, small businesspersons and women, to represent all the trades in the district. The results were analysed using multivariate techniques like linear regression, logistic regression, $t$-test for comparison of means, and chi-square test for the comparison of proportions.

Literature on surplus and constraint examined the impact of the environment predominantly from the lenders' perspective. However, little is understood about the borrower behaviour from the borrowers' perspective, in the surplus and constrained environments. This study addresses this gap and investigates the impact of credit environment on the borrower behaviour.

The results highlight three significant issues. First, the two credit environments differ in default drivers, with the borrowers of larger loans defaulting more in credit surplus, and smaller borrowers striving to preserve the credit opportunity in constraint. Secondly, farmers and farm labourers in surplus receive significantly adverse credit terms compared to constraint. They pay higher interest to moneylenders, are collateralized more often, face longer time-lag for loan approval, and get longer repayment times, but with no prepayment facility, showing that 
surplus does not add to borrower well-being any more than constraint does.

Thirdly, in case of micro-credit, the theory of new institutional economics (NIE), recommended interlinking factor markets like land, labour and credit, for reduced information asymmetry and a reduced cost of borrowing, leading to more efficient outcomes ${ }^{10}$. Our findings confirm the theory of NIE.

\section{Literature review}

\section{Borrowing literature in credit surplus and constrained environments}

Several studies on borrowing note the positive impact of credit access, and the negative influence of constraint on poverty. Credit access impacted livelihoods in Bosnia and Herzegovina and enabled businesspersons to start new businesses more easily in provinces with more MFIs, unlike those with fewer MFIs, where businesses with higher cash-flows or experienced businesspersons alone could start a new business ${ }^{11}$. Microcredit catalysed borrowers' income, wages, and daily percapita expenditure as compared to non-borrowers in Central America and increased the scale and performance of gung-ho enterprises in Hyderabad ${ }^{2,12}$.

\section{Default behaviour in surplus and constrained environments}

In credit surplus, the borrower borrowed from multiple MFIs and repaid only where it was profitable for him to do so. Studies ${ }^{13,14}$ blamed information asymmetry for defaults, where borrowers repaid only when the credit records were public, fearing the loss of future loans. Higher cost of credit led to lenders choosing lemon borrowers, triggering defaults ${ }^{15}$.

Personal effects like age and gender, income as well as loan characteristics like business liability and overindebtedness were linked to defaults. The relatively wealthy defaulted more than the poorer counterparts in India, China and the US, where political clout and inertia drove the defaults ${ }^{16,17}$.

\section{Terms of credit for trades in surplus and constrained environments}

We define terms of credit as collateralization, guarantee as a collateral substitute, loan size, interest rate, time-lag between application and approval of loan, due date or repayment time, lenders' flexibility and prepayments. At the root of credit contracts is the risk-rationing of borrowers, where the poorer, high-risk borrowers were size and non-size rationed in constraint, leading to varying terms of credit across borrower classes.
Credit terms varied because of information asymmetry, leading to either price rationing or quantity rationing. A comparison of the repayment schedules of the banks, the moneylenders, and MFIs in Bangladesh showed important differences ${ }^{18}$. The stringent weekly repayment schedules of MFIs compelled borrowers to invest in rapidly yielding micro-enterprises instead of agriculture, which had a longer maturity rate, effectively linking sources of credit to its uses. Still they held because micro credit supplied credit for private moneylenders in Cambodia ${ }^{19}$. When the borrowers were too poor to offer collateral, substitutes like third party guarantees, pledged savings and unconventional collateral worked in Thailand ${ }^{20}$. Collateralization of formal loans crowded in informal loans from friends and relatives in China and India ${ }^{21}$.

\section{Methodology}

The study is based on a face-to-face survey of 419 borrowers drawn from a village each in the surplus Chittoor (210) and the constrained Nalgonda (209). The survey follows a two-stage cluster sampling. In stage one, the districts of united AP were ranked based on the number of bank-linked SHGs, and the volume of credit disbursed through SHGs. The top and bottom performing districts were chosen for the survey. In stage two, a sample of about 210 borrowers each, comprising of farmers, off-farm workers, small businesspersons, SHG members and cooperative members was selected from the chosen villages, to arrive at a total sample of 419 . We use multivariate techniques like ordinary least square regression; $\chi^{2}$ test for comparison of proportions; $t$-test for comparison of means; and binary logistic regression for data analysis. Table 1 compares the credit flow and demographics in the two sampled villages. Table 2 list the different lenders in credit surplus and constrained environments, the average loan sizes borrowed from each of these lenders and the interest rates therein. Table 2 shows how money lenders are the most expensive source of credit in surplus and SHGs are the least expensive source. In constraint, the interest rates are evenly distributed across lenders, with no lender being significantly more expensive or cheaper than the other. The table further shows how the largest loans in surplus are borrowed from money lenders, while in constraint, the largest loans are sources from friends and relatives. Table 3 presents a comprehensive list of variables - dependent, control and predictors, used in this paper. With the largest amount borrowed (continuous) as a dependent variable, and the rest of the variables in Table 3 as predictors, an OLS regression was run for studying the borrowing drivers, after controlling for credit access (Tables 4 and 5). The binary variable, whether the borrower has defaulted or not, is dependent, and the rest of the variables in Table 3 are predictors for binary logistic regression investing default drivers in surplus and constraint (Tables 6 and 7). Given the significance of trade in 
Table 1. Demographics in surplus (Chittoor) and constraint (Nalgonda)

\begin{tabular}{lcc}
\hline Demographics & Surplus (Chittoor) & Constraint (Nalgonda) \\
\hline Village name & Katappagaripalle & Drisencherla \\
Population* & 2524 & 7077 \\
Number of SHGs in total** & 160 & 110 \\
Population/SHG** & 23 & 44 \\
Total amount disbursed to SHGs (Rs in lakh)** & 226.95 & 48.75 \\
Total amount disbursed per SHG (Rs)** & 217,681 & 30,468 \\
Total amount disbursed per person (Rs)** & 9486 & 689 \\
Age*** & 45 & 42.08 \\
Family size*** & 4.46 & 3.67 \\
No. of earners in the family*** & 1.5 & 2 \\
Monthly income (Rs)*** & 4286.76 & 6908 \\
Education in years*** & 4.52 & 5.7 \\
Farm size in acres*** & 1.61 & 1.77 \\
Income from two crops (Rs)*** & 12,739 & 39,186 \\
Number of banks in the village*** & 3 & 2 \\
Distance to the nearest bank (km)*** & 4 & 2.44 \\
\hline
\end{tabular}

*PCA-CBD-2823-F-Cencus. **Source: SERP-AP and SERP-Telangana websites. ***Source: Survey data.

Table 2. Descriptives for interest rates and loan sizes of various lenders in surplus and constraint

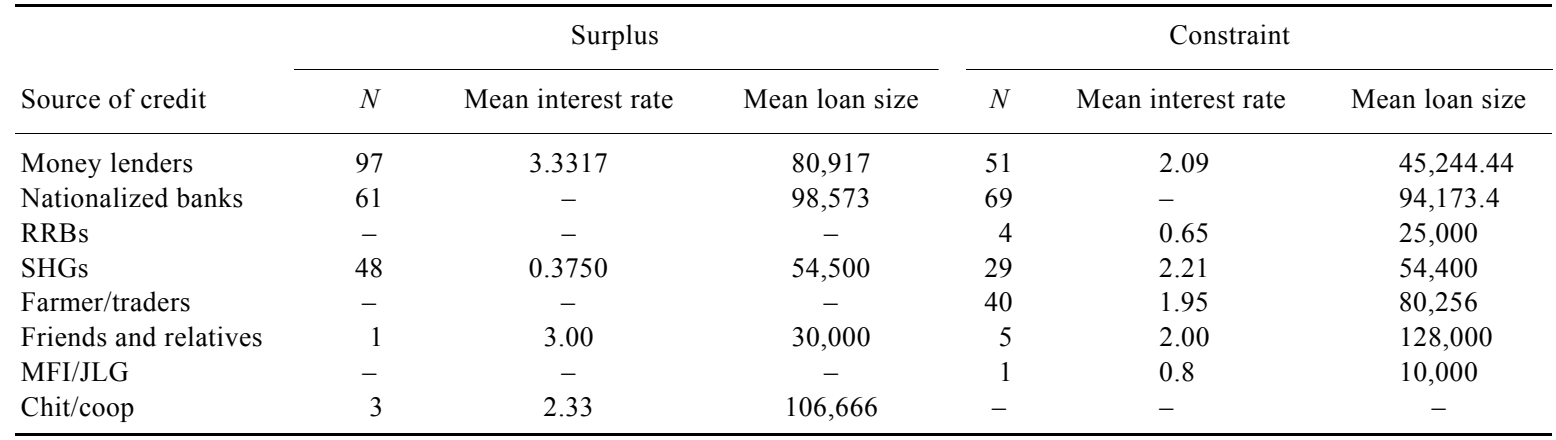

driving defaults in both surplus and constraint, we compare the credit flow across various trades by using one-way ANOVA (Table 8). The study further compares credit terms across trades through chi-square tests, cross tabulation and independent sample $t$-tests (Table 9).

\section{Results}

\section{Borrowing behaviour}

We compare the borrowing drivers between credit surplus and constraint by running an OLS of the top-most loan, a continuous variable, against the predictors listed in Table 3. Results given are in Tables 4 and 5.

Table 4 gives the output of stepwise OLS, comprising the significant predictors of the largest loan in surplus. The table shows the amount defaulted positively, and significantly predicts the amount borrowed at 99\% level. Centred crop income and centred due date negatively impact the amount borrowed at $99 \%$ level, pointing out that larger loans have shorter due dates and are borrowed by those with below-average crop income. The number of earning members in the family positively affects the amount borrowed at $99 \%$ level, while bank distance negatively affects the borrowing amount. Borrowing in surplus is also influenced by gender, with men borrowing larger sums at $95 \%$ confidence interval (CI); and by borrowers' lower preference for credit from friends and relatives, at $99 \% \mathrm{CI}$.

Table 5 lists the borrowing drivers in constraint through OLS, where much like surplus, centred crop income and centred due date negatively influence the amount borrowed at $99 \% \mathrm{CI}$; and male gender has a positive influence on amount borrowed at $95 \% \mathrm{CI}$. Yet a higher preference for investment income as an instalment finance choice, and a lower preference for financing instalments through other sources, influence accessing larger loans, at 99\% CI. Finally, a larger monthly income positively predicts amount borrowed at $95 \% \mathrm{CI}$ in constraint.

Tables 3 and 4 compare and contrast borrowing in surplus and constraint. There are four aspects of borrowing common to both the environments. One, the relatively wealthy borrow more, where wealth is indicated by the number of earning members in the family in surplus, and 
Table 3. Borrowing and repayment variables

\begin{tabular}{|c|c|}
\hline Variable name and description & Variable name and description \\
\hline Loan amount 1 - first loan & Timlag postpone $(1)$ - postpone loan time \\
\hline Repay fail (2) - repaid & Credit preference banks \\
\hline Interest per month $1-$ on first loan & Credit preference SHG-bank loan \\
\hline Loan due date months 1 - for first loan & Credit preference MFI/JLG loan \\
\hline Lendrs flexi (2) - nonflexible lender & Credit preference for SHG own funds \\
\hline Time lag-lag between application and approval & Age \\
\hline Given collateral before? (1) - offered collateral & Family size \\
\hline Given collateral before? (2) - did not offer collaternal & Income per month \\
\hline Guarantee a collateral substitute? (yes/no) & Caste \\
\hline Use of loan 1 & Finances installments through \\
\hline Source of loan 1 & Hnd loans Inst. Fin. (1) hand loan yes \\
\hline Have a bank account (1) - yes & Hnd lons (2) - hand loan - no \\
\hline Have a bank account (2) - no & ML Inst. Fin. (1) - money lender - yes \\
\hline Have chit member (1) - yes & ML Inst. Fin. (2) - money lender - no \\
\hline Have chit member (2) - no & Othr SHG Inst. Fin. (1) \\
\hline Repay priority (1) - first loan repayment is priority & Installment finance through savings (1) \\
\hline Repay priority (2) - second loan payment is priority & Invst Incom Inst. Fins - return on business \\
\hline Total amount defaulted & Installment finance through salary or wages $(1)-$ salary/wages \\
\hline No of months of default & Cut food Inst. Fin. (1) - reduce food \\
\hline Repay fail Lndr - lender type & Cut food Inst. Fin. (2) - do not reduce food \\
\hline Repay fail Lndr (8) gold loans or chit funds & Trade or profession \\
\hline Repay fail Lndr (9) - SHG Own funds & District name \\
\hline Repay fail Lndr (10) - other lenders & \\
\hline
\end{tabular}

monthly income in constraint. Two, women in both the environments borrow less. Three, those with below average crop income borrow more; and four, larger borrowings have lower time for repayment. But there are two differences between the two credit environments. One, in surplus, those who borrow more, default more. Two, in constraint, those who repay loans through investment income, borrow larger amounts, and those who repay loans through other means, borrow smaller amounts.

\section{Default behaviour}

Given the contrasting default behaviour in surplus and constraint while the borrowing drivers remain largely the same, this study considers the variable, has the borrower defaulted, a binary, as a dependent, and considers the rest of the variables in Table 2 as predictors, to run a stepwise binary logistics regression (Tables 5 and 6).

Table 5 shows how surplus loans sourced from moneylenders are less likely to be defaulted at $95 \%$ CI. Similarly, financing instalments from moneylenders' loans reduce default risk at $99 \%$ level. Longer time-lag reduces default risk at $95 \%$ CI. Larger interest rates increase default risk at $95 \%$ level. Instalment finance through hand-loans increases default risk at 95\% CI. Finally, being a businessperson increases the default risk at $99 \% \mathrm{CI}$.

In constraint (Table 6), belonging to $\mathrm{OBC}$ increases the default risk at $99 \% \mathrm{CI}$, while being a woman decreases the default risk at $95 \%$ CI. Being a farm-labourer or a government or private employee decreases the default risk at $99 \%$ level in constraint. If the loan is first in the repayment priority, or is financed through investment income, it is more likely to be defaulted at 95\% level. Yet if the repayment reason is that the loan is not misused, the default risk is lower at $95 \%$ level.

\section{Trades and borrowing}

Since trade is a significant repayment driver in both surplus and constraint, we study the flow of credit 
RESEARCH ARTICLES

Table 4. OLS for amount borrowed in surplus (dependent variable: amount borrowed)

\begin{tabular}{|c|c|c|c|c|c|}
\hline \multirow[b]{2}{*}{ Model } & \multicolumn{2}{|c|}{ Unstandardized coefficients } & \multirow{2}{*}{$\begin{array}{c}\begin{array}{c}\text { Standardized } \\
\text { coefficients }\end{array} \\
\text { Beta }\end{array}$} & \multicolumn{2}{|c|}{ Collinearity statistics } \\
\hline & & & & Tolerance & VIF \\
\hline Constant & $94587.57 * * *$ & 32825.33 & & & \\
\hline Amount defaulted & $3.15 * * *$ & 0.658 & 0.407 & 0.823 & 1.215 \\
\hline Centred due date 1 & $-1902 * * *$ & 401.76 & -0.406 & 0.805 & 1.242 \\
\hline Centred total crop income & $-1.26 * * *$ & 0.355 & -0.28 & 0.957 & 1.045 \\
\hline Number of earning members in family & $40654 * * *$ & 11862.46 & 0.274 & 0.925 & 1.08 \\
\hline Distance to bank (km) & $-13112.77 * * *$ & 3667.31 & -0.294 & 0.876 & 1.14 \\
\hline Credit preference relatives and friends & $13895.4 * * *$ & 4745.9 & 0.249 & 0.821 & 1.217 \\
\hline Gender & $-32608.19 * *$ & 14568.9 & -0.179 & 0.927 & 1.079 \\
\hline
\end{tabular}

$R^{2}$ value is 0.514 and adjusted $R^{2}$ is 0.52 . Standard errors are given in parenthesis. **, *** Represent significance at $95 \%$ and $99 \%$ level respectively.

Table 5. OLS for the amount borrowed in constraint (dependent variable: amount borrowed)

\begin{tabular}{|c|c|c|c|c|c|}
\hline \multirow{3}{*}{$\begin{array}{l}\text { Model } \\
\text { Constant }\end{array}$} & \multirow{2}{*}{\multicolumn{2}{|c|}{$\begin{array}{c}\text { Unstandardized coefficients } \\
\text { B }\end{array}$}} & \multirow{3}{*}{$\begin{array}{c}\begin{array}{c}\text { Standardized } \\
\text { coefficients }\end{array} \\
\text { Beta }\end{array}$} & \multicolumn{2}{|c|}{ Collinearity statistics } \\
\hline & & & & \multirow[t]{2}{*}{ Tolerance } & \multirow[t]{2}{*}{ VIF } \\
\hline & $1,900,097$ & $(48515.8)$ & & & \\
\hline Centred crop income (Rs) & $-0.512 * * *$ & 0.09 & -0.407 & 0.829 & 1.307 \\
\hline Centred due date 1 & $-2437.36 * * *$ & 564 & -0.283 & 0.986 & 1.014 \\
\hline Installment finance investment income & $-56706 * * *$ & 16487 & -0.225 & 0.988 & 1.012 \\
\hline Installment finance other sources & $29677 * * *$ & 10787 & 0.181 & 0.978 & 1.023 \\
\hline Monthly income (Rs) & $5.47 * *$ & $(2.107)$ & 0.178 & 0.901 & 1.109 \\
\hline Gender & $-42698 * *$ & $(16953)$ & -0.172 & 0.906 & 1.103 \\
\hline
\end{tabular}

$R^{2}$ value is 0.514 and adjusted $R^{2}$ is 0.511 . Standard errors are given in parenthesis. **,*** Represent significance at $95 \%$ and $99 \%$ level respectively.

Table 6. Default drivers in surplus (dependent variable: whether the borrower has defaulted or not)

\begin{tabular}{|c|c|c|c|c|c|c|c|}
\hline Trade (business) & 3.82 & 1.417 & 7.268 & $0.007 * * *$ & 45.62 & 2.837 & 733.38 \\
\hline Time-lag & -1.484 & 0.68 & 4.938 & $0.026 * *$ & 0.227 & 0.061 & 0.839 \\
\hline Interest per month & 1.052 & 0.456 & 5.323 & $0.021 * *$ & 2.864 & 1.172 & 7.003 \\
\hline Instalment finance (hand-loans) & 2.508 & 1.063 & 5.565 & $0.018 * *$ & 12.285 & 1.528 & 98.74 \\
\hline
\end{tabular}

**,***Represent $95 \%$ and $99 \%$ significance. Cox and Snell $R^{2}$ is 0.555 ; Nagelkere $R^{2}$ is 0.745 ; Hosemer and Lemeshow test for significance is 0.518 .

across various trades in the two environments (Tables 8 and 9).

Tables 8 and 9 compare the terms of credit across different trades between surplus and constraint. The tables use $t$-statistic for comparison of means, and $\chi$-square test for a comparison of proportions. Comparison of loans sizes across trades reveals that farm labourers in surplus receive more loans than the constraint, at $99 \%$ more significance. There is no significant difference in loan sizes across other trades between surplus and constraint. Similarly, there is no difference across trades with respect to interest rates between surplus and constraint. The timelag between application and approval of loan is more for farmers and farm labourers in surplus than in constraint, again at $99 \%$ level. The due date or repayment time is also significantly more for farmers and farm labourers in surplus, compared to constraint, at $99 \%$ significance level. The farmers in surplus pay significantly more interest rate to moneylenders than those in constraint the $P$-value of $t$-statistic is 0.015 . Farmers and farmlabourers do not find their lenders to be flexible in surplus, more than those in constraint, at 99\% significance. Further, they do not prepay their loans more; offer collateral more often; do not find guarantee as a collateral substitute more often than in constraint; and default more often than those in constraint, at significant levels. The small businesspersons in surplus offer collateral more often than those in constraint. 
RESEARCH ARTICLES

Table 7. Default drivers in constraint (dependent variable: whether the borrower has defaulted or not)

\begin{tabular}{|c|c|c|c|c|c|c|c|}
\hline Variable name & $\mathrm{B}$ & SE & Wald & Sig. & $\operatorname{Exp}(B)$ & \multicolumn{2}{|c|}{$95 \%$ CI for $\exp (B)$} \\
\hline Gender (woman) & -2.937 & 1.313 & 5.007 & $0.025 * *$ & 0.053 & 0.004 & 0.695 \\
\hline Caste (OBC) & 3.792 & 1.21 & 9.816 & $0.002 * * *$ & 44.36 & 4.317 & 475.752 \\
\hline Trade (farm labourer) & -3.53 & 1.345 & 6.903 & $0.009 * * *$ & 0.029 & 0.002 & 0.407 \\
\hline Trade (government/private employee) & -5.21 & 2.281 & 5.213 & $0.022 * *$ & 0.005 & 0.000 & 0.478 \\
\hline Repayment priority (1) & 2.889 & 1.161 & 6.196 & $0.013 * *$ & 17.97 & 1.848 & 174.74 \\
\hline
\end{tabular}

*,*****Represent $90 \%, 95 \%$ and $99 \%$ significance. Cox and Snell $R^{2}$ is 0.335 ; Nagelkere $R^{2}$ is 0.576 ; Hosemer and Lemeshow test for significance is 0.932 .

Table 8. Borrowing across trades in surplus and constraint

\begin{tabular}{|c|c|c|c|c|c|c|}
\hline & \multicolumn{6}{|c|}{ Borrowing variables } \\
\hline & Mean in surplus & Mean in constraint & Difference & Std. error & $t$-value & Significance \\
\hline \multicolumn{7}{|l|}{ Loan amount } \\
\hline Farmers & 108766.6 & 85846.94 & 22,919 & 17,532 & 1.307 & 0.227 \\
\hline Farm laborers & 70183.10 & 37283.78 & 32,899 & 5515.59 & 5.965 & 0.000 \\
\hline Small business & 112600.0 & 76666.67 & 35,933 & 38,919 & 0.923 & 0.391 \\
\hline Government employee & 62500.00 & 79000.00 & $-16,500$ & $36,659.46$ & -0.45 & 0.67 \\
\hline Unemployed & 59333.33 & 78000.00 & $-18,666$ & 43,866 & -0.425 & 0.646 \\
\hline \multicolumn{7}{|l|}{ Interest 1} \\
\hline Farmers & 1.59 & 1.35 & 0.24 & 12.80 & -0.144 & 0.886 \\
\hline Farm laborers & 2.14 & 1.63 & 0.51 & 6.75 & -0.477 & 0.605 \\
\hline Small business & 2.10 & 1.94 & 0.16 & 0.374 & 0.923 & 0.664 \\
\hline Government employee & 3.00 & 1.80 & 1.2 & 0.84 & 1.43 & 0.239 \\
\hline Unemployed & 1.58 & 1.50 & 0.08 & 41.36 & -0.998 & 0.357 \\
\hline \multicolumn{7}{|l|}{ Time-lag loan 1} \\
\hline Farmers & 1.34 & .46 & 0.872 & 0.196 & 4.46 & 0.000 \\
\hline Farm laborers & 1.56 & .46 & 1.103 & 0.226 & 4.885 & 0.000 \\
\hline Small biz & 1.57 & .56 & 1.005 & 0.425 & 2.36 & 0.13 \\
\hline Government employee & .38 & .39 & -0.012 & 0.166 & -0.07 & 0.947 \\
\hline Unemployed & .64 & .96 & -0.325 & 0.308 & -1.057 & 0.321 \\
\hline \multicolumn{7}{|l|}{ Repayment time for loan 1} \\
\hline Farmers & 28.82 & 13.07 & 15.75 & 4.44 & 3.81 & 0.000 \\
\hline Farm laborers & 34.35 & 15.34 & 19.01 & 1.801 & 10.9 & 0.000 \\
\hline Small biz & 35.63 & 15.50 & 20.13 & 15.86 & 0.328 & 0.753 \\
\hline Government employee & 29.50 & 12.00 & 17.5 & 11.76 & 1.49 & 0.187 \\
\hline Unemployed & 29.56 & 18.80 & 10.76 & 5.99 & 1.79 & 0.098 \\
\hline \multicolumn{7}{|l|}{ ML interest } \\
\hline Farmers & 2.83 & 2.19 & 0.64 & 0.244 & 2.32 & 0.015 \\
\hline Farm laborers & 3.24 & 2.26 & 0.98 & 0.214 & 0.726 & 0.395 \\
\hline Small biz & 2.89 & 2.25 & 0.64 & 1.252 & -0.548 & 0.602 \\
\hline Government employee & 4.66 & 2.4 & 2.26 & 0.69 & 1.83 & 0.06 \\
\hline Unemployed & 2.86 & 1.89 & 0.97 & 0.202 & 3.53 & 0.004 \\
\hline
\end{tabular}

\section{Discussion}

The results demonstrate that the relatively wealthy borrow more in both the environments, pointing to a wealth bias in borrowing ${ }^{22,23}$. Interestingly, crop income, another wealth indicator, negatively predicts the borrowing amount, indicating that smaller farmers borrow more. In Tunisia, the loan profiles of larger farmers were different from those of smaller ones, with the former investing more in capital assets ${ }^{3}$. Women in both the environments borrow less, perhaps due to the skewed ownership of immovable property ${ }^{24-26}$.
Nevertheless, the two credit environments contrast in repayment behaviour, with surplus marked by overborrowing and defaults, while constraint is marked by planned borrowing and repayment, pointing to an inherent wealth bias in district selection. Furthermore, in an effort to preserve the scarce credit opportunity, constrained borrowers plan their repayments better ${ }^{6}$.

High interests trigger defaults in surplus ${ }^{27}$. Sourcing loans from moneylender in surplus decreases the chances of default, despite this being the most expensive credit source, in a conscious effort to preserve this source of credit. Yet, serial borrowing and over-indebtedness drive 
RESEARCH ARTICLES

Table 9. Terms of credit across trades in surplus and constraint

\begin{tabular}{|c|c|c|c|c|c|c|c|c|}
\hline \multirow[b]{3}{*}{ Variable } & \multicolumn{8}{|c|}{ Terms of credit } \\
\hline & \multicolumn{2}{|c|}{ Surplus } & \multirow{2}{*}{$\begin{array}{c}\text { Constraint } \\
\text { Yes }\end{array}$} & \multirow{2}{*}{$\begin{array}{l}\chi^{2} \text { value } \\
\text { No }\end{array}$} & \multirow{2}{*}{$\begin{array}{c}\chi^{2} \text { value } \\
\text { significance }\end{array}$} & \multirow{2}{*}{$\begin{array}{l}\text { Continuity } \\
\text { correction }\end{array}$} & \multirow{2}{*}{\multicolumn{2}{|c|}{$\begin{array}{c}P \text {-value for } \\
\text { continuity correction }\end{array}$}} \\
\hline & Yes & No & & & & & & \\
\hline \multicolumn{9}{|l|}{ Lenders' flexibility: Y/N } \\
\hline Farmers & 2 & 23 & 0 & 101 & 24.89 & 0.000 & - & - \\
\hline Farm laborers & 23 & 111 & 1 & 78 & 17.38 & 0.000 & - & - \\
\hline Government employee & 4 & 4 & 5 & 5 & - & - & - & - \\
\hline Unemployed & 1 & 8 & 0 & 7 & 0.83 & 0.362 & 0.00 & 1.00 \\
\hline \multicolumn{9}{|l|}{ Did you prepay the loan? Y/N } \\
\hline Farmers & 0 & 30 & 20 & 79 & 7.854 & 0.049 & - & - \\
\hline Farm laborers & 3 & 139 & 6 & 73 & 3.905 & 0.048 & 2.63 & 0.105 \\
\hline Small biz & 0 & 25 & 2 & 5 & 7.62 & 0.006 & 3.52 & 0.061 \\
\hline Government/private employee & 2 & 2 & 1 & 4 & 0.9 & 0.343 & 0.056 & 0.813 \\
\hline \multicolumn{9}{|c|}{ Have you given collateral before? $\mathrm{Y} / \mathrm{N}$} \\
\hline Farmers & 26 & 4 & 65 & 36 & 5.428 & 0.02 & 4.427 & 0.035 \\
\hline Farm laborers & 99 & 43 & 25 & 53 & 30.74 & 0.00 & - & - \\
\hline Small biz & 19 & 6 & 2 & 5 & 5.453 & 0.02 & 3.55 & 0.059 \\
\hline Government/private employee & 2 & 2 & 2 & 3 & 0.09 & 0.764 & 0.00 & 1.00 \\
\hline Unemployed & 6 & 3 & 2 & 5 & 2.28 & 0.131 & 1.016 & 0.313 \\
\hline \multicolumn{9}{|c|}{ Guarantee a collateral substitute? Y/N } \\
\hline Farmers & 0 & 13 & 50 & 51 & 11.465 & 0.001 & 9.54 & 0.002 \\
\hline Farm labourers & 2 & 45 & 32 & 47 & 20.21 & 0.000 & - & - \\
\hline Small biz & 1 & 7 & 4 & 3 & 3.343 & 0.067 & 1.64 & 0.2 \\
\hline Government/private employee & 1 & 1 & 1 & 4 & 0.63 & 0.427 & 0.00 & 1.00 \\
\hline Unemployed & 0 & 3 & 1 & 6 & 0.476 & 0.49 & 0.00 & 1.00 \\
\hline \multicolumn{9}{|l|}{ Have you defaulted before? Y/N } \\
\hline Farmers & 13 & 17 & 13 & 88 & 13.49 & 0.00 & 11.64 & 0.001 \\
\hline Farm labourers & 51 & 88 & 16 & 62 & 6.127 & 0.013 & 5.39 & 0.02 \\
\hline Small biz & 20 & 5 & 2 & 5 & 6.73 & 0.009 & 4.59 & 0.033 \\
\hline
\end{tabular}

defaults in surplus-financing installments through handloans increasing the default risk. In contrast, in constraint loan characteristics do not matter for defaults, where borrower caste, gender and profession play a more important role, perhaps because constraint adversely affects incomes.

Regarding the flow of credit across trades, farmers and farm labourers receive significantly adverse credit terms and default more in surplus than in constraint. In surplus however, there is no significant improvement in loan size, except for farm labourers, who receive larger loan sizes. The results are self-evident-farm yields per acre in surplus are just about a third of those in constraint, making farming a risky affair. Observable riskiness is linked to higher collateralization because collateral reduces the risk of defaults and borrower runs ${ }^{14,15}$. Consequently, farmers and farm labourers in surplus find guarantors far less often than those in constraint and have to offer a collateral more. Farmers in surplus pay more for moneylenders' credit than their counterparts in constraint, linking trade riskiness to cost of credit. In a Mexico-led cluster, female borrowers depending on uncertain agriculture defaulted as much as men $\operatorname{did}^{6}$. The larger loan sizes, lower crop income, and a higher risk rationing point to the adversity of farmers in AP and Telangana states.

In surplus there is little size rationing, but borrowers are more cost-rationed and risk-rationed. Yet, the expensive moneylenders in surplus are less defaulted on, underscoring their indispensability. In the aftermath of MFI meltdown, there is a disproportionate dependence on money lenders, who seem to have filled the credit vacuum.

The disproportionate dependence on expensive moneylenders despite the presence of pro-poor SHGs points to a competition between the lenders for the same pool of able borrowers, leaving out the poorest in the process, as proved world-over ${ }^{8}$. We notice landless farm labourers receiving particularly adverse credit terms in surplus despite the profusion of the pro-poor SHGs.

Despite fewer bank-linked SHGs, constraint has farmers and traders tilting the scales in borrowers' favour, easing the terms of credit, pointing to the efficiency of interlinking factor markets. These findings confirm the theory of NIE where interlinking land, labour and credit markets are predicted to reduce information asymmetry, transaction costs, leading to more efficiency ${ }^{10}$. In Punjab, in credit layering arrangements, the poorer farmers are directed to borrow from the costlier traders, 


\section{RESEARCH ARTICLES}

while the better-off borrow from the landlords, signaling their credit worthiness. Layering works to overcome information asymmetry, much like the interlinking of factor markets $^{28}$.

\section{Conclusion and policy recommendations}

This study shows how constraint helps better the lending terms, particularly for the poorest, landless labourers.

Filliping the for-profit MFIs alongside the non-profit, NGO-driven SHGs is a step in the right direction, because the MFI meltdown in 2011 pushed up the moneylenders' interest rates, which were arguably filling up the credit vacuum. In such an instance, the onus is on the state to regulate and curb informal lenders, as was done in China $^{18}$. As on 2017, NABARD pumped in Rs 3498 crores to 19 MFIs (Status of Microfinance in India: A NABARD REPORT 2016-17). Nevertheless, the state should monitor the quality of MFI portfolios, to prevent over-lending. MFIs should be encouraged to lend for income-generating activities, while NABARD should create off-farm livelihood opportunities for the landless farm labourers. MFIs should offer credit to farmers and landless labourers in low income districts like Chittoor, at lower interest rates, and with a longer repayment time. Smaller farmers with lower landholding sizes should be prioritized for lending by banks and regional rural banks (RRBs), whose loan schedules and credit terms should be eased.

The allocation for village crop insurance should be revised based on the farm output, where smaller farmers should be prioritized in AP and Telangana states. Farmers should be insured against crop loss and lower farm productivity due to drought and over-indebtedness.

Conflict of interests: The authors declare that there is no conflict of interest in the writing and submission of this article to Current Science. The authors also declare that no financial benefit was accrued from the direct applications of this research.

Funding details. The authors declare that no funding was received for the writing of this research article from any source.

1. Datta, U., Socio-economic impacts of JEEViKA: a large-scale selfhelp group project in Bihar, India. World Develop., 2015, 68, 1-18.

2. Banerjee, A. V., Breza, E., Duflo, E. and Kinnan, C., Do credit constraints limit entrepreneurship? Heterogeneity in the returns to microfinance, 2017.

3. Foltz, J. D., Credit market access and profitability in Tunisian agriculture. Agric. Econ., 2004, 30(3), 229-240.

4. Augsburg, B., De Haas, R., Harmgart, H. and Meghir, C., The impacts of microcredit: evidence from Bosnia and Herzegovina. Am. Econ. J.: Appl. Econ., 2015, 7(1), 183-203.

5. Aubert, C., de Janvry, A. and Sadoulet, E., Designing credit agent incentives to prevent mission drift in pro-poor microfinance institutions. J. Dev. Econ., 2009, 90(1), 153-162.
6. Antonio Bittencourt Marconatto, D., Barin Cruz, L., Legoux, R. and Correa Dantas, D., Microfinance in Latin America and the Caribbean: the influence of territory on female repayment performance in a polarized region. Manage. Decision, 2013, 51(8), 1596-1612.

7. Cull, R., Asli Demirgüç-Kunt, A. and Morduch, J., Microfinance meets the market. J. Econ. Perspect., 2009, 23(1), 167-192.

8. McIntosh, C. and Wydick, B., Competition and microfinance. J. Dev. Econ., 2005, 78(2), 271-298.

9. Pearson, R. S., Relationship banking in a competitive environment with and without information sharing: The importance of credit bureaus in microfinance, Doctoral dissertation, The Ohio State University, 2008.

10. Herath, G., Analysis of the potential and problems of new institutional economics for third world development. Int. J. Soc. Econ., 2005, 32(10), 877-892.

11. Hartarska, V. and Nadolnyak, D., An impact analysis of microfinance in Bosnia and Herzegovina. World Dev., 2008, 36(12), 2605-2619.

12. Hiatt, S. R. and Woodworth, W. P., Alleviating poverty through microfinance: village banking outcomes in Central America. Soc. Sci. J., 2006, 43(3), 471-477.

13. Berger, A. N., Frame, W. S. and Ioannidou, V., Tests of ex ante versus ex post theories of collateral using private and public information. J. Financial Econ., 2011, 100(1), 85-97.

14. Bond, P. and Rai, A. S., Borrower runs. J. Dev. Econ., 2009, 88(2), 185-191.

15. Stiglitz, J. E. and Weiss, A., Credit rationing in markets with imperfect information. Am. Econ. Rev., 1981, 71(3), 393-410.

16. Kropp, J. D., Turvey, C. G., Just, D. R., Kong, R. and Guo, P., Are the poor really more trustworthy? A micro-lending experiment. Agric. Finance Rev., 2009, 69(1), 67-87.

17. Tsai, K. S., Imperfect substitutes: the local political economy of informal finance and microfinance in rural China and India. World Dev., 2004, 32(9), 1487-1507.

18. Dalla Pellegrina, L., Microfinance and investment: a comparison with bank and informal lending. World Dev., 2011, 39(6), 882-897.

19. Ovesen, J. and Trankell, I. B., Symbiosis of microcredit and private money lending in Cambodia. Asia Pac. J. Anthropol., 2014, 15(2), 178-196.

20. Menkhoff, L., Neuberger, D. and Rungruxsirivorn, O., Collateral and its substitutes in emerging markets' lending. J. Bank. Finance, 2012, 36(3), 817-834.

21. Turvey, C. G. and Kong, R., Informal lending amongst friends and relatives: can microcredit compete in rural China? China Econ. Rev., 2010, 21(4), 544-556.

22. Barham, B. L., Boucher, S. and Carter, M. R., Credit constraints, credit unions, and small-scale producers in Guatemala. World Dev., 1996, 24(5), 793-806.

23. Kochar, A., An empirical investigation of rationing constraints in rural credit markets in India. J. Develop. Econ., 1997, 53(2), 339-371.

24. Sandhu, N., Hussain, J. and Matlay, H., Barriers to finance experienced by female owner/managers of marginal farms in India. J. Small Bus. Enterprise Dev., 2012, 19(4), 640-655.

25. Rao, S., Reforms with a female face: gender, liberalization, and economic policy in Andhra Pradesh, India. World Dev., 2008, 36(7), 1213-1232.

26. Fletschner, D., Rural women's access to credit: market imperfections and intrahousehold dynamics. World Dev., 2009, 37(3), 618-631.

27. Pereira, S. and Mourao, P., Why does the microcredit borrowing rate differ across countries? A cross-country study. Int. J. Soc. Econ., 2012, 39(8), 536-550.

28. Mansuri, G., Credit layering in informal financial markets. $J$. Develop. Econ., 2007, 84(2), 715-730.

Received 10 December 2018; revised accepted 8 April 2019

doi: $10.18520 / \mathrm{cs} / \mathrm{v} 117 / \mathrm{i} 2 / 227-234$ 